\title{
Climate-Relevant Ocean Transport Measurements in the Atlantic and Arctic Oceans
}

\begin{abstract}
By Barbara Berx, Denis Volkov, Johanna Baehr, Molly O. Baringer, Peter Brandt, Kristin Burmeister, Stuart Cunningham, Marieke Femke de Jong, Laura de Steur, Shenfu Dong, Eleanor Frajka-Williams, Gustavo J. Goni, N. Penny Holliday, Rebecca Hummels, Randi Ingvaldsen, Kerstin Jochumsen, William Johns, Steingrimur Jónsson, Johannes Karstensen, Dagmar Kieke, Richard Krishfield, Matthias Lankhorst, Karin Margetha H. Larsen, Isabela Le Bras, Craig M. Lee, Feili Li, Susan Lozier, Andreas Macrander, Gerard McCarthy, Christian Mertens, Ben Moat, Martin Moritz, Renellys Perez, Igor Polyakov, Andrey Proshutinsky, Berit Rabe, Monika Rhein, Claudia Schmid, Øystein Skagseth, David A. Smeed, Mary-Louise Timmermans, Wilken-Jon von Appen, Bill Williams, Rebecca Woodgate, and Igor Yashayaev
\end{abstract}

Ocean circulation redistributes heat, freshwater, carbon, and nutrients all around the globe. Because of their importance in regulating climate, weather, extreme events, sea level, fisheries, and ecosystems, large-scale ocean currents should be monitored continuously. The Atlantic is unique as the only ocean basin where heat is, on average, transported northward in both hemispheres as part of the Atlantic Meridional Overturning Circulation (AMOC). The largely unrestricted connection with the Arctic and Southern Oceans allows ocean currents to exchange heat, freshwater, and other properties with polar latitudes.
A number of observational arrays, shown in Figure 1, together with the main circulation features, have been established across the Atlantic and in the Arctic Oceans to improve our understanding of and to monitor changes in the AMOC, as well as large-scale changes in water mass properties (e.g., temperature, salinity) and ocean transports (how much heat or salt is transported by currents). The arrays incorporate multiple observing platforms such as ship-based hydrographic transects, submarine cable measurements, moored sensor arrays (see Figure 2) at a number of latitudes, surface drifters, satellite observations,
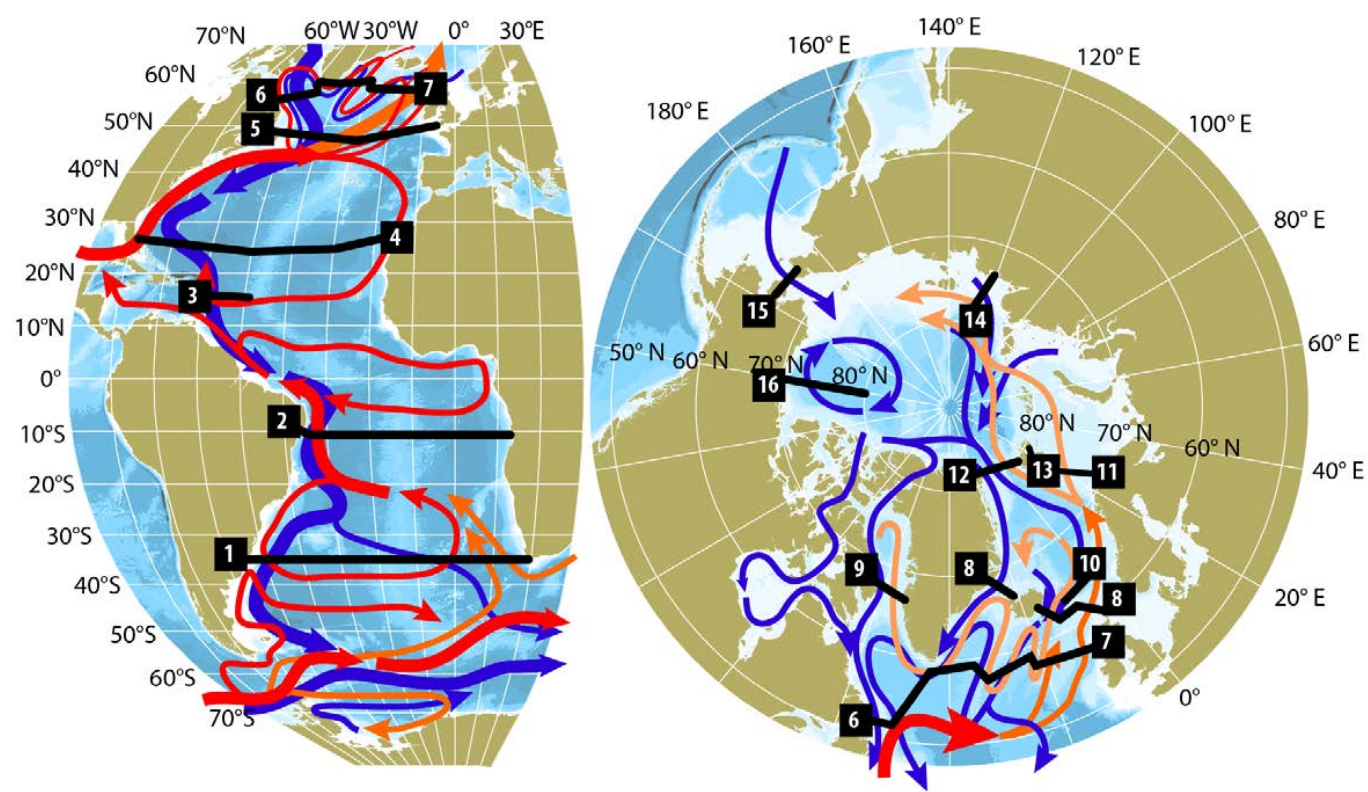

FIGURE 1. A schematic of the ocean transport observing systems in the Atlantic and Arctic Oceans. Circulation arrows are general representations of the warm, salty, and less dense upper limb of the Atlantic Meridional Overturning Circulation (AMOC) (red and orange arrows) and its cold, fresh, dense lower limb (blue arrows). (1) South Atlantic MOC Basin-wide Array at $34.5^{\circ} \mathrm{S}$ (SAMBA). (2) Tropical Atlantic Circulation and Overturning at $11^{\circ} \mathrm{S}$ (TRACOS). (3) Meridional Overturning Variability Experiment at $16^{\circ} \mathrm{N}$ (MOVE). (4) The RAPID-MOCHA-WBTS array at $26.5^{\circ} \mathrm{N}$. (5) The North Atlantic Changes array at $47^{\circ} \mathrm{N}$ (NOAC). (6) The Overturning in the Subpolar North Atlantic Program (OSNAP) West array. (7) OSNAP East array. (8) the Greenland-Scotland Ridge (GSR) arrays. (9) Davis Strait array. (10) Svinoy mooring array. (11) Barents Sea Opening array. (12) Fram Strait array. (13) Longterm variability and trends in the Atlantic Water inflow region (ATWAIN) array. (14) Nansen and Amundsen Basin Observing System (NABOS). (15) Bering Strait array. (16) Beaufort Gyre Observing System (BGOS). 


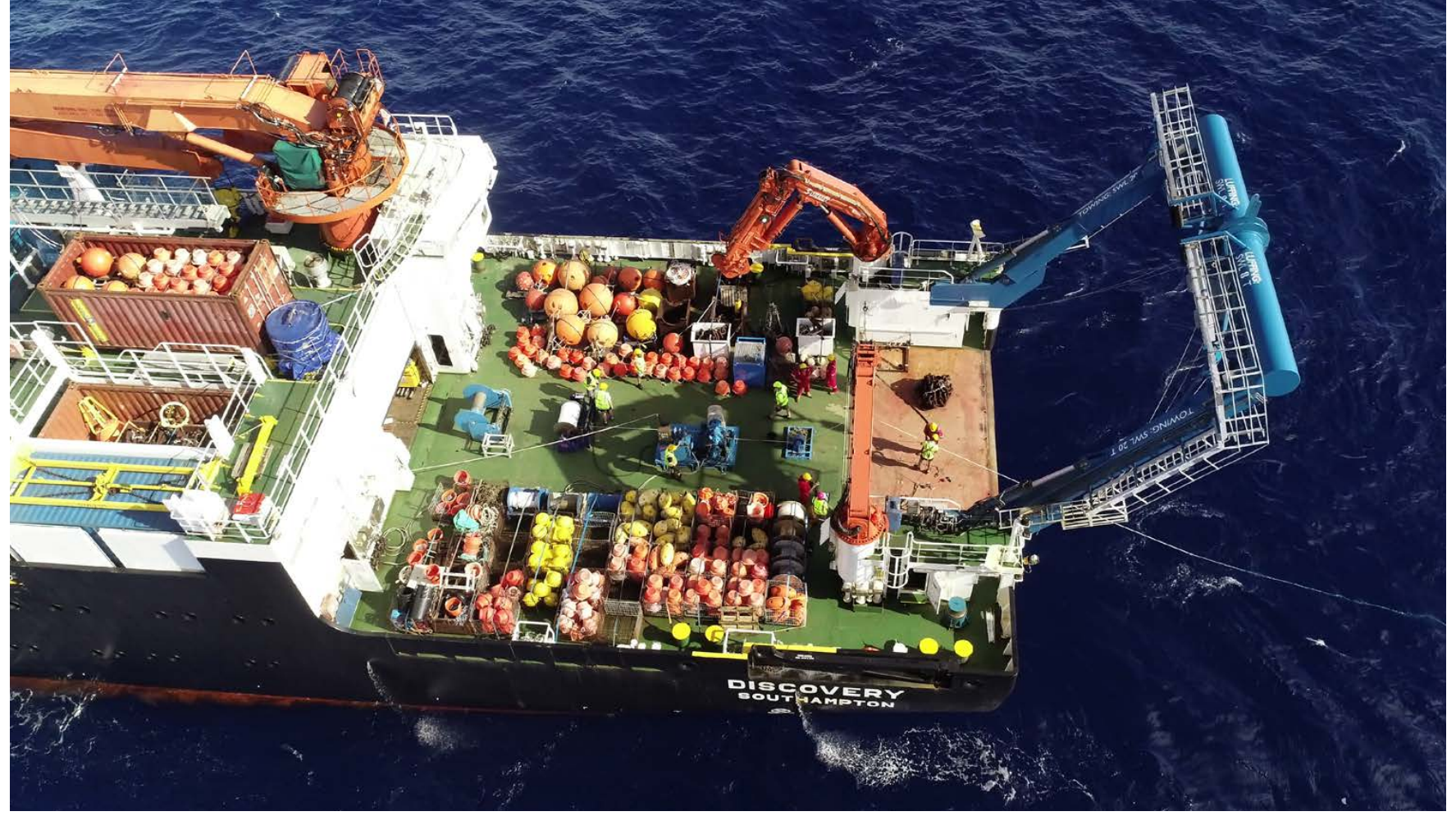

FIGURE 2. An Atlantic mooring is deployed from RRS Discovery during cruise DY129 in early 2021. Photo credit: Pete Brown, NOC

expendable bathythermographs, and Argo floats (FrajkaWilliams et al., 2019; Østerhus et al., 2019).

These observational arrays contribute to the Global Ocean Observing System (GOOS) via the Observing Coordination Groups (OCG) networks. Increasingly, interdisciplinary and international collaboration are ensuring that these arrays quantify more than solely the physical ocean circulation and its transports of heat and salt. For example, sensors that can detect oxygen and nitrate concentrations, $\mathrm{pH}$, the partial pressure of $\mathrm{CO}_{2}$, and seawater optical properties have been added, along with water samplers, to a number of arrays to quantify biogeochemical fluxes.

While the building blocks of the arrays are nationally funded and organized (often with shorter funding periods that can jeopardize the sustained effort), it is the international collaboration and coordination that makes them truly basin-wide and allows them to bridge borders and disciplines. Moreover, the data collection efforts often bring opportunities for testing technological advances and for training early career scientists and those from developing nations.

Existing observations have greatly advanced our knowledge of large-scale ocean circulation variability at various timescales and provided first insights into its links to weather, ecosystems, and regional sea levels. The arrays continue to provide new and essential knowledge of oceanic processes. This leads to better representation of the physics in ocean and coupled models and, consequently, to reduced uncertainties in climate and operational predictions. Sustained observations remain critical for monitoring and understanding how Earth's climate system responds to global warming and for assessing the imprints of this response on society's development of climate adaptation strategies. It remains important to reconcile the results from different arrays using new technologies and improved methodologies in order to reduce uncertainties in the estimates of oceanic transports. Continued global collaboration, evaluation of the different critical components of the observing system, improving visibility of the observational array components in GOOS, and engagement with end users will be critical to ensure the sustained effort of these arrays.

In summary, the global community has been obtaining critical environmental information by measuring ocean transports at different locations in the Atlantic and at the Arctic Ocean gateways. Continued efforts based on these observational arrays are paramount to understanding and adapting to the impacts of climate and weather on humans and Earth's natural resources on land and in the ocean.

\section{REFERENCES}

Frajka-Williams, E., I.J. Ansorge, J. Baehr, H.L. Bryden, M.P. Chidichimo, S.A. Cunningham, G. Danabasoglu, S. Dong, K.A. Donohue, S. Elipot, and others. 2019. Atlantic Meridional Overturning Circulation: Observed transport and variability. Frontiers in Marine Science 6:260, https://doi.org/10.3389/fmars.2019.00260.

Østerhus, S., R. Woodgate, H. Valdimarsson, B. Turrell, L. de Steur, D. Quadfasel, S.M. Olsen, M. Moritz, C.M. Lee, K.M.H. Larsen, and others. 2019. Arctic Mediterranean exchanges: A consistent volume budget and trends in transports from two decades of observations. Ocean Science 15:379-399, https://doi.org/10.5194/os-15-379-2019.

ARTICLE DOI: https://doi.org/10.5670/oceanog.2021.supplement.02-04 


\section{AUTHORS}

Barbara Berx (b.berx@marlab.ac.uk), Marine Scotland Science, UK. Denis Volkov, NOAA Atlantic Oceanographic and Meteorological Laboratory (NOAA/AOML), and University of Miami, USA. Johanna Baehr, Universität Hamburg, Germany. Molly O. Baringer, NOAA/AOML, USA. Peter Brandt, GEOMAR Helmholtz Centre for Ocean Research Kiel, Germany. Kristin Burmeister and Stuart Cunningham, Scottish Association for Marine Science, UK. Marieke Femke de Jong, Royal Netherlands Institute for Sea Research, Netherlands. Laura de Steur, Norwegian Polar Institute, Norway. Shenfu Dong, NOAA/AOML, USA. Eleanor Frajka-Williams, National Oceanography Centre, Southampton, UK. Gustavo J. Goni, NOAA/AOML, USA. N. Penny Holliday, National Oceanography Centre, Southampton, UK. Rebecca Hummels, GEOMAR Helmholtz Centre for Ocean Research Kiel, Germany. Randi Ingvaldsen, Institute of Marine Research, Norway. Kerstin Jochumsen, Bundesamt für Seeschifffahrt und Hydrographie, Germany. William Johns, Rosenstiel School of Marine and Atmospheric Science, University of Miami, USA. Steingrimur Jónsson, University of Akureyri, Iceland. Johannes Karstensen, GEOMAR Helmholtz Centre for Ocean Research Kiel, Germany. Dagmar Kieke, University of Bremen, Germany. Richard Krishfield, Woods Hole Oceanographic Institution (WHOI), USA. Matthias Lankhorst, Scripps Institution of Oceanography, University of California San Diego, USA. Karin Margetha H. Larsen, Faroe Marine Research Institute, Faroe Islands. Isabela Le Bras, WHOI, USA.

Craig M. Lee, Applied Physics Laboratory, University of Washington, USA. Feili Li, Xiamen University, China. Susan Lozier, Georgia Institute of Technology, USA. Andreas Macrander, Marine and Freshwater Research Institute, Iceland. Gerard McCarthy, Maynooth University, Ireland. Christian Mertens, University of Bremen, Germany. Ben Moat, National Oceanography Centre, Southampton, UK. Martin Moritz, Bundesamt für Seeschifffahrt und Hydrographie, Germany. Renellys Perez, NOAA/AOML, USA. Igor Polyakov, University of Alaska Fairbanks, USA. Andrey Proshutinsky, WHOI, USA. Berit Rabe, Marine Scotland Science, UK. Monika Rhein, University of Bremen, Germany. Claudia Schmid, NOAA/AOML, USA. Øystein Skagseth, Institute of Marine Research, Norway. David A. Smeed, National Oceanography Centre, Southampton, UK. Mary-Louise Timmermans, Yale University, USA. Wilken-Jon von Appen, Alfred Wegener Institute, Germany. Bill Williams, Institute of Ocean Sciences, Canada. Rebecca Woodgate, Applied Physics Laboratory, University of Washington, USA. Igor Yashayaev, Department of Fisheries and Oceans and Bedford Institute of Oceanography, Canada.

\section{ARTICLE CITATION}

Berx, B., D. Volkov, J. Baehr, M.O. Baringer, P. Brandt, K. Burmeister, S. Cunningham, M.F. de Jong, L. de Steur, S. Dong, E. Frajka-Williams, G.J. Goni, N.P. Holliday, R. Hummels, R. Ingvaldsen, K. Jochumsen, W. Johns, S. Jónsson, J. Karstensen, D. Kieke, R. Krishfield, M. Lankhorst, K.M.H. Larsen, I. Le Bras, C.M. Lee, F. Li, S. Lozier, A. Macrander, G. McCarthy, C. Mertens, B. Moat, M. Moritz, R. Perez, I. Polyakov, A. Proshutinsky, B. Rabe, M. Rhein, C. Schmid, Ø. Skagseth, D.A. Smeed, M.-L. Timmermans, W.-J. von Appen, B. Williams, R. Woodgate, and I. Yashayaev. 2021. Climate-relevant ocean transport measurements in the Atlantic and Arctic Oceans. Pp. 10-11 in Frontiers in Ocean Observing: Documenting Ecosystems, Understanding Environmental Changes, Forecasting Hazards. E.S. Kappel, S.K. Juniper, S. Seeyave, E. Smith, and M. Visbeck, eds, A Supplement to Oceanography 34(4), https://doi.org/10.5670/oceanog.2021.supplement.02-04.

\section{COPYRIGHT \& USAGE}

This is an open access article made available under the terms of the Creative Commons Attribution 4.0 International License (https://creativecommons.org/ licenses/by/4.0/), which permits use, sharing, adaptation, distribution, and reproduction in any medium or format as long as users cite the materials appropriately, provide a link to the Creative Commons license, and indicate the changes that were made to the original content. 